\title{
¿Cuál es su diagnóstico?
}

\section{What would your diagnosis be?}

Varón de 82 años, no fumador, con hipertensión arterial en tratamiento y EPOC severo con oxigenoterapia domiciliaria y corticoterapia como antecedentes importantes de interés. Es remitido por su odontólogo a urgencias del Hospital Universitario La Paz, al presentar en encía mandibular edéntula una tumoración de aspecto úlcero-necrótico de $1 \mathrm{~cm}$ de diámetro de 4 semanas de evolución. En la anamnesis, el paciente refiere haber sido tratado por su odontólogo con antibioterapia y antiinflamatorios, dado el diagnóstico de presunción de absceso odontogénico, sin mejorìa del cuadro (Fig. 1). Como síntoma principal presenta intenso dolor en encía afecta y mandíbula subyacente con hipoestesia en territorio del nervio dentario inferior izquierdo. No aqueja disfagia ni odinofagia.

A la exploración física, no drena material purulento, ni espontáneamente ni a la compresión de la lesión,

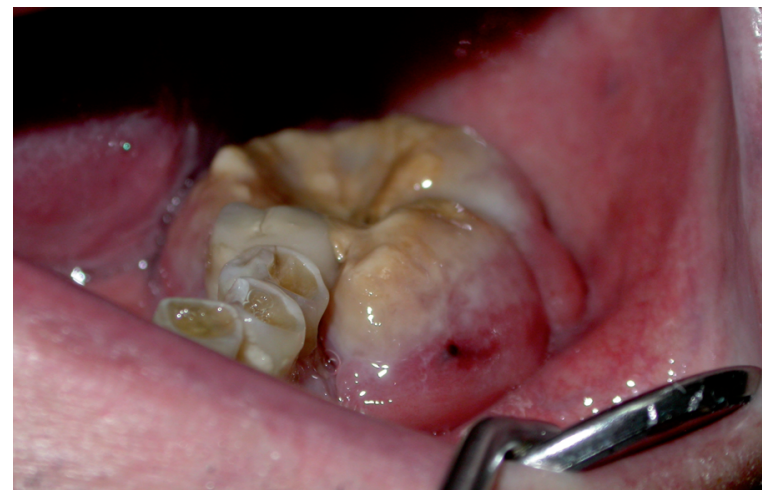

Figura 1. Imagen clínica intraoral de la lesión mandibular. Figure 1. Clinical intraoral view of the mandibular lesion.

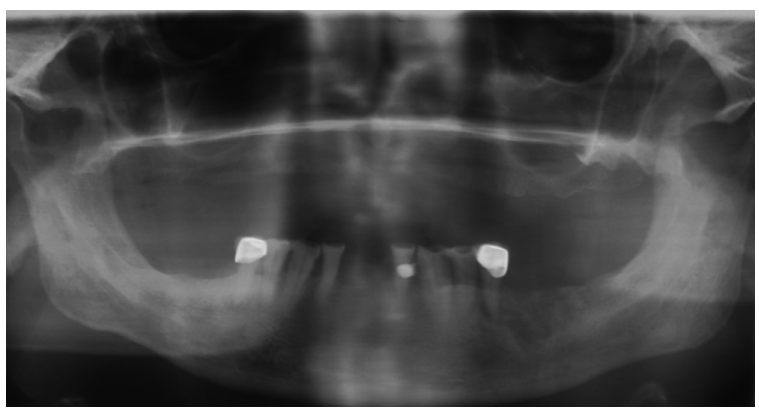

Figura 2. Ortopantomografía que objetiva la erosión ósea mandibular.

Figure 2. Panorex view showing the bone mandibular erosion.
Male, 82 years old, non smoker being treated for hypertension and severe COPD, he has a history of in home oxygen therapy and cortical therapy. His dentist sent him to the emergency room at University Hospital of La Paz because of a tumor on the gum "mandibular edentia" the tumor has an ulcer-necrotic appearance and is 1 $\mathrm{cm}$ in diameter and 4 weeks progressed. During anamnesis the patient reports that his dentist treated him with antibiotherapy and anti-inflammato$r y$, given the presumed diagnosis as a dental abscess, without improvement of the square (Fig. 1). The main symptoms are intense pain in the affected gum and subjacent mandible, and hypoesthesia in the area surrounding the left inferior dental nerve. It doesn't cause dysphagia or odynophagia. Upon physical exploration there is no purulent material drained. Nor is there active bleeding even when pressure is applied to the lesion. There was no trismus, perceived upon ballooning palpation of the mandible cortical vestibuasí como tampoco presenta sangrado activo. Ausencia de trismus, apreciando a la palpación, abombamiento de la cortical vestibular mandibular. Ausencia de otras lesiones en cavidad oral ni se palpan adenopatías cervicales. En el estudio radiológico, la ortopantomografía muestra una imagen osteolítica en sector edéntulo del tercer cuadrante mandibular correspondiente a piezas 35-37. La imagen se extiende a los 2/3 superiores de la altura del cuerpo mandibular (Fig. 2). La TC corrobora la presencia de lesión osteolítica mandibular de patrón difuso y afectación de la cortical vestibular mandibular. Destaca la existencia de lesión de $2 \times 1 \mathrm{~cm}$ con centro necrótico, en partes blandas correspondiente a encía suprayacente (Fig. 3). Se realiza biopsia de la lesión con curetaje de hueso alveolar. El análisis anatomopatológico e inmunohistoquímico es informado de células linfoproliferativas monoclonales tipo $B$ de fenotipo CD 20+, CD 79a+. La serología es negativa para VIH, citomegalovirus, VHB y VHC. lar. There were no other lesions of adeonpathies felt in the oral cavity. In a radiological study the ortopantomography shows the osteolytic image of the edentulous sector of the third mandible quadrant which corresponds to teeth 35-37. The image extends to the 2/3 superiors and to the height of the mandible body (Fig. 2). The CT verifies the presence of an osteolytic mandible lesion with a vague pattern and cortical vestibular mandible affectation. It highlights the existence of a $2 \times 1 \mathrm{~cm}$ lesion with a necrotic center in soft parts of the corresponding super adjacent gum (Fig. 3). A biopsy of the lesion is carried out with alveolar bone curettage. The anatomopatological and inmunohistochemistry analyses are informed about the lympho proliferative monoclonal cells type $B$ and phenotype $C D 20+, C D 79 a+$. The serology is negative for HIV, cytomegalovirus, $H B V$, and $H C V$. 


\title{
Linfoma no-hodgkin de alto grado primario mandibular
}

\author{
High level primary mandible non Hodgkin's lymphoma
}

\author{
L. Pingarrón Martín, J. Arias Gallo, E. Mirada, M.J.Morán, E. Palacios, M. Burgueño
}

Los linfomas son tumores hematológicos derivados del sistema reticulo-endotelial y linfático. Son los tumores malignos más frecuentes en territorio de cabeza y cuello, sólo superados por el carcinoma epidermoide.

Tradicionalmente clasificados como linfoma Hodgkin y No-Hodgkin (LNH), la enfermedad de Hodgkin afecta fundamentalmente a ganglios mediastínicos y cervicales, mientras que los linfomas noHodgkin hasta en un $40 \%$ de los casos se manifiestan como enfermedad extranodal. De este $40 \%$, un $2-3 \%$ se origina de forma primaria en territorio maxilar-mandibular y en la cavidad oral. ${ }^{1}$

El LNH comprende un grupo de enfermedades malignas del sistema linforeticular caracterizadas por la expansión clonal de linfocitos, fundamentalmente células $B$ y menos frecuentemente de la línea celular $\mathrm{T}$, en varios niveles de desarrollo ontogenético.

El subtipo más prevalente es el LNH de células grandes (hasta un $40-58 \%$ de todos los $\mathrm{LNH}$, dependiendo de la serie revisada), subtipo correspondiente al caso clínico que se presenta..$^{1-3}$

El LNH oral a menudo se trata de un componente dentro de un proceso patológico diseminado con implicación de adenopatías regionales, siendo de muy infrecuente presentación como enfermedad extranodal primaria en cavidad oral o en maxilares. Éstos últimos son los huesos craneofaciales con mayor frecuencia de afectación de los linfomas óseos. El riesgo de padecimiento de LNH se incrementa en el caso de pacientes con trastornos autoinmunes (como el síndrome de Sjögren) siendo la estirpe predominante linfomas de células B.

\footnotetext{
Médico residente

\section{Correspondencia:}

Dra. Lorena Pingarrón Martín

Servicio de Cirugía Oral y Maxilofacial

Hospital Universitario La Paz.

po de la Castellana, 261

28046 Madrid. España
}

Servicio de Cirugía Oral y Maxilofacial. Hospital Universitario La Paz. Madrid. España
The lymphomas are haematological tumors derived from the lymphatic and reticuloendothelial system. They are the most frequent malignant tumors in the head and neck, the only tumor that is more common is epidermoid carcinoma.

Traditionally classified as Hodgkin and Non-Hodgkin lymphoma (NHL), the Hodgkin disease fundamentally affects the mediastinal and cervical node while $40 \%$ of NonHodgkin's cases are classified as extra nodal diseases. 2-3\% of this $40 \%$ start its primary form in the maxilla-mandible zone and in the oral cavity. ${ }^{1}$

The NHL contains a group of malignant diseases of the lymph reticular system characterized by clonal expansion of lymphocytes, mainly B cells and less commonly of the T cell line, at various levels of ontogenetic development.

The most prevalent subtype is NHL of large cells (up to $40-58 \%$ of all of the NHL, depending on the series reviewed) ${ }^{1-}$ 3 subtype corresponding to the clinical case that is presented. Oral NHL is usually made up of a component within a disseminated pathological process with implications of regional adenopathies. It does not usually appear as a primary extra nodal disease in the oral cavity or in maxillas. These last ones are from craniofacial bones that have the most frequent affectation of the bone lymphomas. Risk of NHL disease increases in patient with autoimmune disorders (for example Sjögren syndrome) being the predominant lymphoma origin of B cells.

One of the main problems in diagnosing $\mathrm{NHL}$ is its great variety of symptoms. Besides its principal nodular location, the rest of the organs, particularly those composed of lymphoid, can be affiliated with lymphoma development, enabling them to be primary and secondary tumors (in disseminated forms).

Immunohistological laboratory analysis and Southern blot are the main ways to diagnose and characterize NHL's. These forms provide critical information that guides clinicians in appropriate protocol and treatment. ${ }^{4}$

According to the majority of authors, in particular Urquhart et al. who provides a large series of cases totaling 235 NHL patients affected in the head and neck, there 
Uno de los principales problemas diagnósticos de los LNH es su gran variabilidad de síntomas. Pese a que la localización nodular es la principal, el resto de órganos, particularmente aquellos de composición linfoide, pueden ser subsidiarios de desarrollar un linfoma, pudiendo ser tumores primarios o secundarios (en las formas diseminadas).

El principal medio de diagnóstico y caracterización de los LNH es el análisis de laboratorio inmunohistoquímico y Southern blot, los cuales proporcionan la información crítica para guiar a los clínicos en el adecuado protocolo de tratamiento. 4

Según la gran mayoría de autores, de los cuales Urquhart et al., presenta la mayor serie de casos con un total de 235 pacientes con $\mathrm{LNH}$ en territorio de cabe-

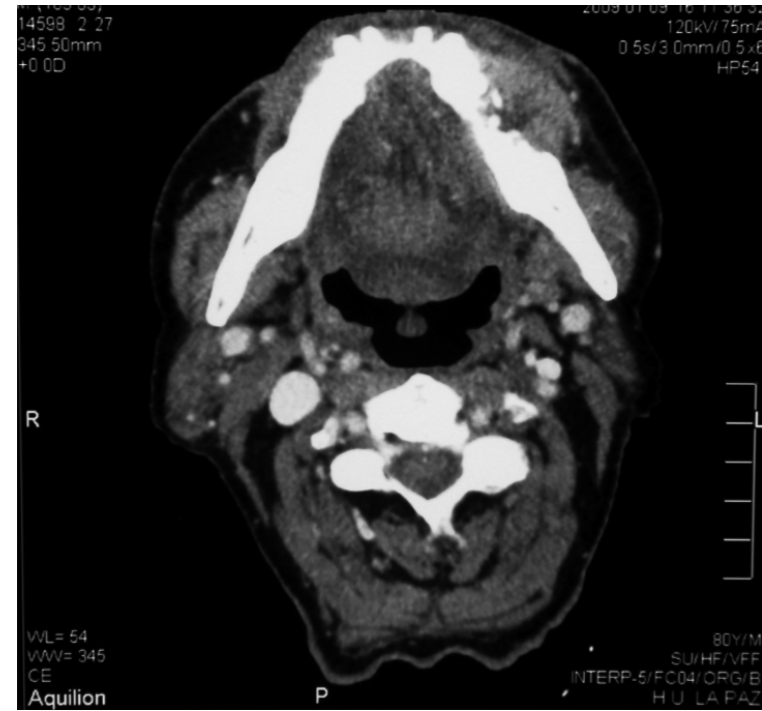

Figura 3. TC con lesión osteolítica mandibular subyacente a tumoración en encía.

Figure 3. CT with mandibular lysis underneath the gum tumor.

is no significant predominance in one sex, but other studies show a predominance of oral cavity NHL disease with a ratio of 3:2 men: women. ${ }^{4}$

In accordance with the case that we provide, all of the series in the literature revised agree that an intraoral tumor is a principle sign that these tumors are present and usually followed by signs of ulceration and radiographic bone destruction. ${ }^{1}$ While the series of 16 patients studied by Djavanmardi et al. ${ }^{2}$ pain is chosen as the principle symptom, equally as common, as the intra oral tumor. He documented ulceration in only $6.25 \%$ of cases and a predominant occurrence of oral NHL like dental hypoesthesia and dental mobility.

nificativo en cuanto a sexos, pero otras series muestran un predominio de padecimiento de LNH de cavidad oral en hombres con ratio hombre:mujer de 3:2.4

Coincidiendo con el caso que se presenta, todas la series de la literatura revisada coinciden en la existencia de tumoración intraoral, como signo principal de presentación de estos tumores, $1,2,4$ seguido de signos como la ulceración y la destrucción ósea radiográfica, ${ }^{1}$ mientras que la serie de 16 pacientes recogida por Djavanmardi et al., ${ }^{2}$ recoge el dolor como síntoma principal, en igual frecuencia, que la tumoración intraoral, documentando la ulceración en sólo un $6,25 \%$ de los casos, con predominio de presentación del LNH oral como hipoestesia y movilidad dental.

En un principio, estos síntomas pueden inducir a un diagnóstico erróneo por parte del odontólogo o el médico en relación a patología infecciosa odontogénica.

El rango de edad media en el momento del diagnóstico es muy amplio, con tendencia de afectación en la edad adulta, con un pico de edad entre los 40 a los 70 años.

El virus Epstein Barr (EBV) se asocia en especial al linfoma Burkitt, pudiendo asociarse estos tumores linfoproliferativos a otros virus como el de la hepatitis $C$, el virus herpes tipo 8 , o el virus de inmunodeficiencia humana (VIH), lo que hace obligado descartar serología positiva en todo paciente con lesiones orales sospechosas de linfoma. ${ }^{6}$

El diagnóstico del LNH está basado principalmente en el análisis morfológico, histológico y citológico y debe ser confirmado inmunológicamente.

Una vez confirmado el diagnóstico, la estadificación es clínica y radiológica.

El pronóstico no depende de la multiplicidad de hallazgos clínicos, sino principalmente de la histología y el estadio tumoral (si está localizado o diseminado, el estadio evolutivo, el número de localizaciones extranodales...). La edad también es un factor pronóstico importante.
At the beginning these symptoms can lead to the dentist or doctor to falsely diagnosing the infectious dental pathology. The average age range at the time of diagnosis is very broad, although affectation tends to be more common in adults with a peak age between 40 and 70 years old.

Epson Barr Virus (EBV) is especially associated with Burkitt, allowing us to make a correlation between these lympho proliferative tumors and other viruses such as Hepatitis C, Herpes Virus Type 8 or HIV. This makes it necessary to dismiss positive serology for all patients who have oral lesions where there are suspicions of lymphoma. ${ }^{6}$

Diagnosis of NHL is mainly based on morphological, histological and cytological analysis which should be immunlologically confirmed.

Once the diagnosis is confirmed the classification is clinical and radiological.

The prognosis doesn't depend on the number of clinical discoveries but rather it depends on the histology and state of the tumor (if it is localized or disseminated, its state of development, the number of extra nodal localizations...) Age is also an important prognostic factor.

The position of the tumor doesn't appear to be a determining factor in prognosis. The Maxillas are an uncommon place and establishment (primary mandible NHL makes up $8 \%$ of mandible tumors and $0.6 \%$ of the total $\mathrm{NHL}$ ) but the frequency increases when found in the Waldeyer ring (extra nodal localization in the head and neck is most frequent), ventilated cavities of solid facial (assume up to one third of extra nodal NHL's), salivary glands and oral mucosa (in order of decreasing frequency).

The prognosis of patients with lymphoma is, in general, better than in patient with epidermoid carcinoma. The survival rate after 5 years is 73\% for those with Hodgkin's lym- 
La localización del tumor no parece ser un factor determinante del pronóstico. Los maxilares es un lugar poco frecuente e asentamiento (el LNH primario mandibular supone el $8 \%$ de los tumores mandibulares y el $0,6 \%$ del total de $\mathrm{LNH}$ ) pero la frecuencia de presentación aumenta en el caso de localizarse en el anillo de Waldeyer (localización extranodal en territorio de cabeza y cuello más frecuente), cavidades aireadas del macizo facial (suponen hasta un tercio de los LNH extranodales), glándulas salivares y mucosa oral (en orden decreciente de frecuencia).

El pronóstico de los paciente con linfoma es, por lo general, mejor que los pacientes con carcinoma epidermoide; la supervivencia a los 5 años se estima en un 73\% para el linfoma Hodgkin y en un $65 \%$ para el linfoma no-Hodgkin extranodal de cabeza y cueIlo. ${ }^{4}$

En base a los criterios de malignidad y el índice pronóstico, se define la estrategia de tratamiento con radioterapia (35-40 Gy), asociada o no a diferentes protocolos de quimioterapia(CHOP: ciclofosfamida, adriamicina, vincristina, prednisolona; ACVBP: adriamicina, ciclofosfamida, vindesina, bleomicina, prednisolona). Esta combinación está principalmente recomendada en linfomas localizados de alto grado.7

Una vez conseguida la remisión total del tumor, el objetivo del seguimiento clínico es la detección temprana de posibles recidivas. Debe realizarse seguimiento del paciente durante 10 años, con examen clínico cada 3 meses durante los primeros 5 años tras la remisión, y en ausencia de hallazgos patológicos, continuar con revisiones anuales.

\section{Discusión}

El linfoma es la segunda patología maligna de cavidad oral más frecuente.

El diagnóstico del LNH está basado principalmente en el análisis morfológico, histológico y citológico y debe ser confirmado inmunológicamente.

Debemos realizar un diagnóstico diferencial fundamentalmente con el carcinoma de células escamosas, tumor más prevalente en territorio de cabeza y cuello, para lo cual nos valemos de la biopsia de la lesión. La biopsia debe ser lo suficientemente amplia como para permitir el estudio morfológico y patológico, cultivo y análisis inmunohistoquímico. Importante enfatizar que una biopsia superficial, con escasa obtención de tejido, puede llevar a un diagnóstico erróneo.

El estadificación del tumor es clínica y radiológica. Según el estadio tumoral se define la estrategia terapéutica.

En el caso de linfomas no-Hodgkin localizados, la radioterapia ha demostrado ser el tratamiento más eficaz necesitando o no asociar quimioterapia en base a la agresividad del tumor.

La cirugía solamente es útil para el diagnóstico de la lesión y para la extirpación de tumores de pequeño tamaño.

Una exhaustiva exploración oral y de los ganglios linfáticos cervicales es fundamental para la identificación de lesiones que pudieran representar un linfoma, debiendo estar siempre en la mente del cirujano maxilofacial esta patología como posibilidad diagnóstica. phoma and $65 \%$ for those with extra nodal non Hodgkin's in the head and neck. ${ }^{4}$

Based on the criteria of malignancy and the prognostic index, a strategic treatment is defined which includes radiotherapy (35-40 Gy) associated or un associated to different chemotherapy protocols (CHOP, cyclophosphamide, adriamicine, vincristine, prednisolone; $A C V B P$ : adriamicina cyclophophamide, vindesine, bleomicin, prednisolone) This combination is mainly recommended for high level localized lymphomas. ${ }^{7}$

Once total remission of the tumor is accomplished, the objective of clinical follow-up is early detection of possible relapses. Patient follow-up should take place for 10 years including a clinical exam every 3 months during the first 5 years after remission, and in the absence of pathological discoveries, annual reviews should continue.

\section{Discussion}

Lymphoma is the second most frequent malignant pathology of the oral cavity.

NHL diagnosis is mainly based on morphological, histological, and cytological analysis and should be immunologically confirmed.

We should carry out a differential diagnosis mainly for squamous carcinoma cells, the most prevalent tumor in the head and neck region. A biopsy is necessary for this differential diagnosis. The biopsy should be wide enough to allow morphological, pathological and cultured studies as well as an immunohistochemistry analysis. It is important to emphasize that the superficial biopsy, with scarce tissue obtaining, can lead us to an erroneous diagnosis.

Classification of the tumor is clinical and radiological. A therapeutic strategy is chosen based on the state of the tumor.

In localized non Hodgkin's cases, radiotherapy has proved to be the most efficient treatment needing or not needing to associate chemotherapy on the basis of an aggressive tumor.

Surgery is only useful in lesion diagnosis and for excision of small tumors.

An exhaustive oral and cervical lymphatic ganglion exploration is fundamental in identifying lesions that could depict lymphoma. The possibility of this pathology should always considered by maxillofacial surgeons as a potential diagnosis. 


\section{Bibliografía}

1. Kemp S, Gallagher G, Kabani S, Noonan V, O’Hara C. Oral non-Hodgkin's lymphoma: review of the literature and World Health Oraganization classification with referente to 40 cases. Oral Surg Oral Med Oral Path Oral Radiol Endod 2008;105:194-201.

2. Djavanmardi L, Oprean N, Alantar A. Malignant non-Hodgkin's lymphoma (NHL) of the jaws: A review of 16 cases. / Craniomaxillofac Surg 2008;36:410-4.

3. Epstein JB, Epstein JD, Le ND, Gorsky M. Characteristics of oral and paraoral malignant lymphoma: a population-based review of 361 cases. Oral Surg Oral Med Oral Pathol Oral Radiol Endod 2001;92:51925.
4. Nocini P, Lo Muziol, Fior A, Staibano S,Mignogna MD. Primary nonHodgkin's lymphoma of the jaws: inmunohistochemical and genetic review of 10 cases. J Oral Maxillofac Surg 2000;58:636-44.

5. Urquhart A, Berg R. Hodgkin's and non-Hodgkin's lymphoma of the head and neck. Laryngoscope 2001;111:1565-9.

6. Balasubramaniam R, Goradia A, Turner L.N, Stoopler E.T, Alawi F, Frank D.M, Greenberg M.S. Burkitt lymphoma of the oral cavity: an atypical presentation. Oral Surg Oral Med Oral Pathol Oral Radiol Endod 2009;107:240-5.

7. Ugar D.A, Turner M, Memis L. Primary lymphoma of the mandibule: report of a case. J Oral Maxillofac Surg 1995; 53:827-9.

\section{Fe de erratas}

Debido a un error en el artículo "Evaluación electromiográfica de los músculos masticadores durante la fuerza máxima de mordedura", publicado en el Volumen 30 n6 Noviembre-Diciembre de 2008 se publicó:

\section{EN RESUMEN}

Dónde se leía: La fuerza de mordedura se determinó con un transductor de presión que era un tubo de goma conectado a un sensor de presión (MPX 5700) (Motorola SPS, Austin, TX, EE.UU.).

Debería poner: La fuerza de mordedura se determinó con un transductor metallic que era conectado a un sensor de fuerza (Strain Gauge) para medición de la deformación del material modelo SF04 (EMG SYSTEM DO BRASIL).

Inglés. The bite force was measured with a metallic transducer that was connected to a force sensor (Strain Gauge) to measure the deformation of the material model SF04 (EMG SYSTEM DO BRASIL).

\section{EN TEXTO}

Dónde se leía: La fuerza de mordedura se determinó con un transductor de presión que era un tubo de goma conectado a un sensor de presión (MPX 5700) (Motorola SPS, Austin, TX, EE.UU.).

Debería poner: La fuerza de mordedura se determinó con un transductor metallic que era conectado a un sensor de fuerza (Strain Gauge) para medición de la deformación del material modelo SF04 (EMG SYSTEM DO BRASIL).

Inglés. The bite force was measured with a metallic transducer that was connected to a force sensor (Strain Gauge) to measure the deformation of the material model SFO4 (EMG SYSTEM DO BRASIL). 